\title{
RECONHECIMENTO SOCIAL
}

A categoria "luta pelo reconhecimento", proposta por Hegel desde os "escritos de Jena", está sendo reatualizada e reintroduzida no debate filosófico e das ciências sociais para explicar as origens dos conflitos sociais. Essa categoria analítica foi retomada no debate entre Charles Taylor (filósofo político canadense que considera 0 reconhecimento social como o vínculo fundamental entre os sujeitos), Axel Honneth e Nancy Fraser. A discussão tem seu ponto alto na proposta de Fraser da existência de três categorias de justiça: reconhecimento social, redistribuição igualitária e representação política. Além dos livros de Charles Taylor, Argumentos filosóficos (2000) e As Fontes do Self(2005), publicados pela Editora Loyola, 0 professor José Henrique de Faria (UFPR e FAE-PR), juntamente com seu grupo de pesquisa Economia Política do Poder, oferece indicações para 0 aprofundamento do assunto.

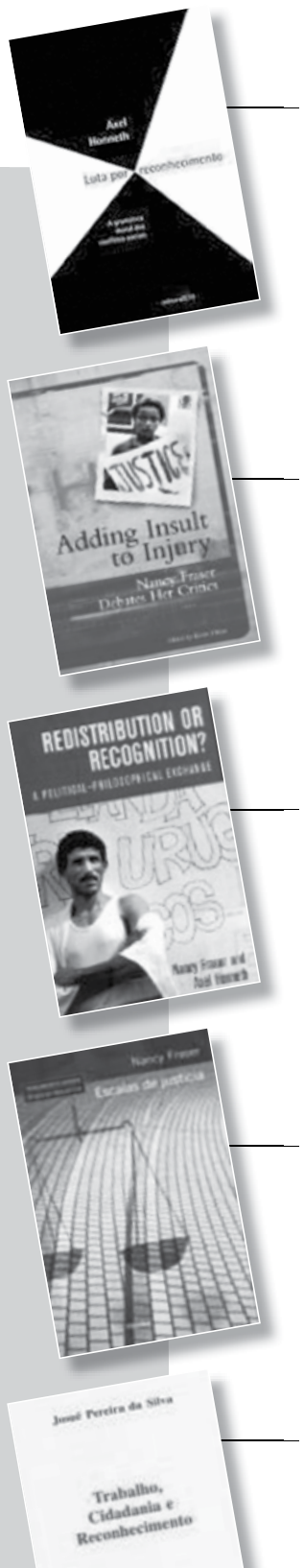

LUTA POR RECONHECIMENTO: A gramática social dos conflitos sociais. Axel Honneth. 2. ed. São Paulo: 34, 2009. 291 p. Axel Honneth, filósofo e sociólogo frankfurtiano da terceira geração, postula uma investigação empírica no campo da sociologia do reconhecimento. Neste livro, publicado originalmente em 1992, apresenta a concepção do monismo normativo em que concebe o reconhecimento social como categoria moral abrangente fundamental, considerando a redistribuição uma subvariante da luta pelo reconhecimento. Honneth recupera o conceito hegeliano de luta por reconhecimento e busca em Winnicott a base empírica para suas argumentações.

ADDING INSULT TO INJURY: Nancy Fraser debates her critics. Nancy Fraser. London: Verso, 2008. 360 p. Nancy Fraser é uma cientista política norte-americana que se dedica aos estudos dos movimentos sociais e dos conflitos políticos. Ao entrar no debate sobre reconhecimento social e redistribuição da riqueza com Honneth, propondo um novo modelo analítico, recebeu críticas de diversos pesquisadores. Este livro apresenta as principais críticas feitas às concepções de Fraser e suas réplicas, constituindo uma importante referência para as discussões do tema.

REDISTRIBUTION OR RECOGNITION? A political-philosophical exchange. Nancy Frasere Axel Honneth. London: Verso, 2003. 276 p. Este livro apresenta o primeiro grande debate entre Fraser e Honneth, com direito a réplicas e tréplicas. Fraser critica Honneth e seu monismo normativo, propondo uma perspectiva dualista, que considera as categorias da redistribuição e do reconhecimento como cofundamentais e como categorias mutuamente irredutíveis. 0 livro apresenta pontos de concordância e discordância entre Fraser e Honneth, sendo as críticas de Fraser mais agudas e empiricamente consistentes.

ESCALAS DE JUSTICIA. Nancy Fraser. Barcelona: Herder, 2008. 294 p. Embora tenha introduzido a dimensão política em suas análises anteriores, neste livro, Fraser revisa suas teorias e estabelece as bases da sua proposta tridimensional, com a inclusão de uma nova categoria: a da representação. Para Fraser, a avaliação da justiça deve ser considerada com base em três dimensões irredutíveis entre si e separadas apenas analiticamente: reconhecimento social (dimensão cultural); redistribuição igualitária (dimensão econômica); representação paritária (dimensão política).

TRABALHO, CIDADANIA E RECONHECIMENTO. Josué Pereira da Silva. São Paulo: Annablume, 2008. 165 p. Josué P. da Silva, professor de sociologia do IFCH da Unicamp, apresenta o resultado de suas pesquisas com a crise da sociedade do trabalho e com a questão da cidadania, tomando por base as discussões da teoria crítica social contemporânea. 0 resultado é 0 enfrentamento das crises teóricas e empíricas para ampliar a compreensão da sociedade atual. No livro, 0 autor mostra criticamente o distanciamento da teoria crítica social contemporânea com os temas do trabalho e da produção. 